$0.84, p<0.001$, respectively). Improvements in all SF-36 subscales were observed in the GLM group at Wks $8 \& 16$ compared to PBO $(p<0.01$, with the exception of the role-emotional subscale $[p=0.058])$. The percentage of pts achieving clinically meaningful change (5 points or greater) in SF-36 PCS \& MCS were higher in GLM than PBO in Wks 8 \& 16 (PCS: 58.1 vs. $27.2,67.6$ vs. 35.9 , respectively; MCS: 48.6 vs. $34.0,54.3$ vs. 29.1 , respectively; $p<0.05$ for all). Mean EQ-5D VAS improvements were greater $(p<0.001)$ in GLM than PBO at Wks 8 \& 16 (17.61 vs. $6.63,20.32$ vs. 4.79 , respectively). Greater improvements in ASQoL were observed in GLM compared to PBO at Wks 8 \& 16 (-4.5 vs. $-1.5, p<0.001$, -5.4 vs. $-1.8, p<0.001$, respectively). By Wk 28 , after PBO crossed-over to GLM, improvement in PCS, MCS, EQ-5D VAS, \& ASQoL were similar between the two treatment arms.

Table: Summary of mean (standard deviation) changes in SF-36, EQ-5D, and ASQoL.

\begin{tabular}{|l|l|c|c|}
\hline & & $\begin{array}{c}\text { IV } \\
\text { GOLIMUMAB } \\
2 \mathrm{mg} / \mathrm{kg}\end{array}$ & PLACEBO \\
\hline Patients & & 105 & 103 \\
\hline $\begin{array}{l}\text { Mean (SD) change from } \\
\text { baseline in SF-36 PCS: }\end{array}$ & Week 8 & $\begin{array}{c}6.83(6.90) \\
(p<0.001)\end{array}$ & $2.07(5.66)$ \\
\hline & Week 16 & $\begin{array}{c}8.52(7.54) \\
(p<0.001)\end{array}$ & $2.87(6.11)$ \\
\hline & Week 28 & $9.08(8.02)$ & $9.29(7.09)$ \\
\hline $\begin{array}{l}\text { Mean (SD) change from } \\
\text { baseline in SF-36 MCS: }\end{array}$ & Week 8 & $\begin{array}{c}5.56(9.26) \\
(p=0.006)\end{array}$ & $1.67(8.80)$ \\
\hline & Week 16 & $\begin{array}{c}6.47(9.12) \\
(p<0.001)\end{array}$ & $0.84(9.82)$ \\
\hline & Week 28 & $6.16(10.91)$ & $5.60(9.70)$ \\
\hline $\begin{array}{l}\text { Mean (SD) change from } \\
\text { baseline in EQ-5D VAS: }\end{array}$ & Week 8 & $\begin{array}{c}17.61(24.02) \\
(p<0.001)\end{array}$ & $6.63(19.881)$ \\
\hline & Week 16 & $\begin{array}{c}20.32(24.59) \\
(p<0.001)\end{array}$ & $4.79(23.47)$ \\
\hline & Week 28 & $20.52(27.86)$ & $22.45(23.08)$ \\
\hline $\begin{array}{l}\text { Mean (SD) change from } \\
\text { baseline in ASQoL: }\end{array}$ & Week 8 & $\begin{array}{c}-4.5(4.71) \\
(p<0.001)\end{array}$ & $-1.5(3.90)$ \\
\hline & Week 16 & $\begin{array}{c}-5.4(5.01) \\
(p<0.001)\end{array}$ & $-1.8(4.50)$ \\
\hline & Week 28 & $-5.3(5.24)$ & $-5.3(4.84)$ \\
\hline
\end{tabular}

Conclusions: Adult pts w/active AS treated w/IV GLM showed marked improvements in physical functioning, mental health functioning, health state, \& HRQoL.

Disclosure of Interest: J. Reveille Grant/research support from: Janssen Scientific Affairs, LLC., A. Deodhar Grant/research support from: Janssen, Amgen, Abbvie, GSK, Eli Lilly, Novartis, Pfizer, UCB, Consultant for: Janssen, Eli Lilly, Novartis, Pfizer, UCB, E. Chan Employee of: Janssen Global Services, LLC, S. Peterson Employee of: Janssen R\&D, LLC, N. Li Employee of: Janssen R\&D, LLC, E. Hsia Employee of: Janssen R\&D, LLC, L. Kim Employee of: Janssen R\&D, LLC, K. H. Lo Employee of: Janssen R\&D, LLC, D. Harrison Employee of: Janssen R\&D, LLC, C. Han Employee of: Janssen Global Services, LLC DOI: 10.1136/annrheumdis-2017-eular.6145

\section{AB0693 PATIENTS WITH CHRONIC INFLAMMATORY ARTHROPATHIES TREATED WITH GOLIMUMAB ACHIEVE A HIGHER SERUM LEVEL OF DRUG IF USED AS THE FIRST OR SECOND BIOLOGICAL DRUG}

J. Rosas $^{1}$, M. Marco-Mingot ${ }^{2}$, J.M. Senabre-Gallego ${ }^{1}$, F. Llinares-Tello ${ }^{2}$, A. Pons ${ }^{1}$, X. Barber ${ }^{3}$, G. Santos-Soler ${ }^{1}$, E. Salas ${ }^{1}$, C. Cano ${ }^{1}$, M. Lorente ${ }^{1}$, M. Sanchís-Selfa ${ }^{3}$, J. Molina ${ }^{2}$, M. García-Carrasco ${ }^{4}$ on behalf of AIRE-MB Group. ${ }^{1}$ Rheumatology Department; ${ }^{2}$ Laboratory Department, Hospital Marina Baixa, Villajoyosa (Alicante); ${ }^{3} \mathrm{ClO}$, Universidad Miguel Hernández, Elche, Spain; ${ }^{4}$ Rheumatology Department, Universidad Autómoma de Puebla, Puebla, Mexico

Objectives: To know the influence of the order of introduction of Golimumab (GLM), on clinical efficacy in ankylosing spondylitis (AS), psoriatic arthritis (PSA) and rheumatoid arthritis (RA).

Methods: A prospective, observational study, in 46 consecutive patients with AS, APS and RA, treated with GLM. Data: epidemiological, concomitant DMARD, time of disease evolution, HLA-B27, RF and ACPA; from GLM: order of introduction, time in treatment, serum level and anti-GLM Ab. The clinical response was assessed in AS patients using BASDAI, BASFI, ASDAS-VSG. In patients with RA or peripheral APS, DAS28-VSG, DAS28-PCR and SDAl. Serum levels of GLM and anti-GLM Ab were determined by ELISA (Progenika, Grifols SA, Spain). Serum cutoff levels for serum GLM levels: $36 \mathrm{ng} / \mathrm{mL}$ and for anti-GLM Ab: UA $>20$ $\mathrm{AU} / \mathrm{mL}$. Samples were extracted just prior GLM administration (trough level) and stored frozen at $-80^{\circ} \mathrm{C}$ until analysis.

Results: Of $33(72 \%)$ AS patients: $52 \%$ were males, mean age $53 \pm 12$ years, mean BML $28 \pm 4$, disease mean evolution $16 \pm 12$ years and in GLM: $1.3+1.1$ years, $30 \%$ received DMARD, being GLM the first anti-TNF in $25 \%$, second $37 \%$, third $25 \%$ and fourth in $13 \%$. The mean GLM level was $0.77 \pm 0.62 \mathrm{mg} / \mathrm{mL}$ and the prevalence of anti-GLM antibodies was $6 \%$. In the 5 patients with RA and 8 with APS: $23 \%$ were men, mean age of $55 \pm 11$ years, mean BMI $28 \pm 6$, mean disease evolution of $10.5 \pm 8$ years and in GLM of $2 \pm 1.5$ years, the $85 \%$ of patients received DMARD, being GLM the first anti-TNF in 31\%, second 15\%, third $31 \%$ and fourth $23 \%$. The mean GLM level was $0.703 \pm 0.53 \mathrm{mg} / \mathrm{L}$. No anti-GLM Ab were detected.

Table 1. Characteristics of patients with receiving GLM, according to the order of introduction

Golimumab (GLM) RA-APS (n: 13) $\quad 1^{\circ}-2^{\circ}$ anti-TNF (n: 7) $\quad 3^{\circ}-4^{\circ}$ Anti-TNF (n: 6) $\quad p$

BMl $\mathrm{kg} / \mathrm{m}^{2}:$ mean (SD)

$\begin{array}{lccc} & 28,72(6,62) & 28,93(6,66) & 0,95 \\ \text { Disease evolution (years): mean (SD) } & 10,1(7,64) & 11,53(10) & 0,78 \\ \text { DMARD, } \mathrm{n}(\%) & 7(100) & 4(67) & 0,13\end{array}$

DMARD, n (\%)

Years on GLM: mean (SD)

anti-GLM Ab, U/L, n (\%)

DAS28-VSG, mean (SD)

DAS28-PCR, mean (SD)

$2,27(1,86)$

0

$1,74(0,83)$

$1,82(0,85)$

$4(67)$

$2,5(2,04)$

0

SDAl, mean (SD)

$3,92(5,17)$

$2,12(0,94)$

$2,28(0,93)$

$7,67(6,58)$

BMI, $\mathrm{kg} / \mathrm{m}^{2}$ : mean (SD)

Disease evolution (years): mean (SD)

DMARD, n (\%)

$1^{\circ}-2^{\circ}$ anti-TNF (n: 21$) \quad 3^{\circ}-4^{\circ}$ anti-TNF (n: 12$)$

$27,46(4,20)$

$14,25(10,55)$

$8(38 \%)$

$1,75(1,47)$

(Sears on GLM: mean (SD)

GLM level, mg/dL: mean (SD)

anti-GLM Ab, U/L, n (\%)

BASDAI: mean (SD)

$0,919(0,63)$

0

$5,96(2,48)$

$2,92(0,87)$

$29,26(3,09)$

$20,65(14,27)$

$2(17)$

$1,13(0,89)$

$0,448(0,47)$

2 (17)

$6,10(2,23)$

$3,79(2,68)$

0,16

0,21

0,57

0,57

0,025

ASDAS: mean (SD)

Conclusions: 1 . The overall prevalence of anti-GLM Ab was $6 \%$ and $17 \%$ in AS patients. Not detecting in patients with RA or PSA. 2. Serum GLM level was higher among the patients receiving it as the 1st or 2nd anti-TNF. 3. In AS GLM as $3 \mathrm{rd}$ or 4 th anti-TNF were able to achieve clinical remission, similar to that achieved as 1st or 2nd drug.

Acknowledgements: The study was supported by a grant from the Fundación Española de Reumatología (FVR/2012) and the Asociación para la Investigación en Reumatología de la Marina Baixa (AIRE-MB).

Disclosure of Interest: None declared

DOI: 10.1136/annrheumdis-2017-eular.4308

\section{AB0694 RHEUMATOLOGISTS' ATTRIBUTION OF PATIENT-REPORTED SYMPTOMS IN AXIAL SPONDYLOARTHRITIS (AXSPA): IMPACT ON RESPONSE TO TNF-INHIBITORS (TNFI) IN 508 PATIENTS}

L. Gossec, A. Moltó, A. Etcheto, N. Boudersa, P. Claudepierre, N. Roux,

F. Berenbaum, A. Martin, L. Sparsa, P. Coquerelle, M. Soubrier, S. Perrot,

M. Dougados. Predict-SpA Study Group, Paris, France

Background: In axSpA, treatment decisions are mainly based on patient-reported symptoms: recommendations are to initiate TNFi in patients with active disease and with physician conviction that treatment is needed (ref). However, the attribution of symptoms to inflammation is difficult to establish in axSpA.

Objectives: The objective of the present analysis was to explore the link between physician-attributed causality for symptoms and treatment response to TNFi.

Methods: The PredictSpA study (ClinicalTrials.gov: NCT03039088) was a longitudinal observational multicenter study in France in 2015. Patients with physician-defined definite axSpA and starting a TNFi treatment were included, a TNFi was prescribed according to usual practice and efficacy was assessed at 12 weeks by BASDAI50 response. At baseline, symptoms levels including BASDAI and ASDAS were collected and the physician evaluated the causality of symptoms by answering the following 3 questions: how convinced are you that the symptoms of this patient are due to (A) inflammatory axSpA activity (B) to axSpA severity (eg syndesmophytes, kyphosis) and NOT to disease activity and (C) to other diseases and NOT axSpA. Each question was assessed 0-10 (not convinced at all to absolutely convinced). The link between a score $\geq 4 / 10$ on each of the 3 questions and BASDAI50 response was assessed by univariate logistic regression. Patients interrupting the TNFi before 3 months were considered as non-responders and missing data were imputed using non-responder imputation. Results: In all, 519 patients were included and 508 had data over 3 months: mean age 41.3 (SD 11.6) years, mean disease duration 6.1 (SD 8.4) years, 237 $(46.7 \%)$ were women, $424(83.5 \%)$ satisfied the ASAS criteria for axSpA of whom $379(74.6 \%)$ were in the imaging arm and $45(8.9 \%)$ in the clinical arm. Symptom levels were high: mean BASDAI was 5.7 (SD 1.8) and mean ASDAS-CRP was 3.3 (SD 0.9) with only $6(1.2 \%)$ patients in inactive disease state according to ASDAS. The physician-attributed causality of symptoms was mostly related to inflammatory activity: mean scores for $(A),(B)$ and $(C)$ were respectively, 7.4 (SD 2.0), 2.3 (SD 2.5) and 2.1 (SD 2.2). When physicians attributed causality to non-axSpA (score $(C)>4 / 10$ ), BASDAI50 response was less frequent: $45 / 118$ $(38.4 \%)$ vs $213 / 390(54.6 \%)$, odds ratio 0.5 [95\% Cl $0.3,0.8]$.

Conclusions: In axSpA patients starting a TNFi with high symptom levels, physician-attributed causality of symptoms was mainly related to inflammatory activity of the axSpA. When physician-attributed causality was more oriented towards non-axSpA causes, BASDAI50 response after 3 months of a TNFi was lower. This confirms the validity of the ASAS-EULAR recommendations for starting a TNFi which rest on a level of symptoms but associated to physician conviction of the indication.

References:

[1] van der Heijde D, et al. 2016 update of the ASAS-EULAR management 